\title{
Cardioprotection Induced by Remote Ischemic Preconditioning Preserves the Mitochondrial Respiratory Function in Acute Diabetic Myocardium
}

\author{
I. KANCIROVÁ ${ }^{1}$, M. JAŠOVÁ ${ }^{1}$, M. MURÁRIKOVÁ ${ }^{1}$, Z. SUMBALOVÁ ${ }^{2}$, O. ULIČNÁ ${ }^{2}$, \\ T. RAVINGEROVÁ ${ }^{1}$, I. WACZULÍKOVÁ ${ }^{3},{ }^{\dagger}$ A. ZIEGELHÖFFER ${ }^{1}$, M. FERKO ${ }^{1}$ \\ ${ }^{1}$ Institute for Heart Research, Slovak Academy of Sciences, Centre of Excellence of SAS NOREG, \\ Bratislava, Slovak Republic, ${ }^{2}$ Pharmacobiochemical Laboratory, Third Department of Internal \\ Medicine, Faculty of Medicine, Comenius University, Bratislava, Slovak Republic, ${ }^{3}$ Department of \\ Nuclear Physics and Biophysics, Faculty of Mathematics, Physics and Informatics, Comenius \\ University, Bratislava, Slovak Republic
}

Received March 26, 2016

Accepted October 26, 2016

\section{Summary}

A $2 \times 2$ factorial design was used to evaluate possible preservation of mitochondrial functions in two cardioprotective experimental models, remote ischemic preconditioning and streptozotocininduced diabetes mellitus, and their interaction during ischemia/reperfusion injury (I/R) of the heart. Male Wistar rats were randomly allocated into four groups: control (C), streptozotocin-induced diabetic (DM), preconditioned (RPC) and preconditioned streptozotocin-induced diabetic (DM+RPC). RPC was conducted by 3 cycles of 5-min hind-limb ischemia and 5min reperfusion. DM was induced by a single dose of $65 \mathrm{mg} / \mathrm{kg}$ streptozotocin. Isolated hearts were exposed to ischemia/ reperfusion test according to Langendorff. Thereafter mitochondria were isolated and the mitochondrial respiration was measured. Additionally, the ATP synthase activity measurements on the same preparations were done. Animals of all groups subjected to I/R exhibited a decreased state 3 respiration with the least change noted in DM+RPC group associated with no significant changes in state 2 respiration. In RPC, DM and DM+RPC group, no significant changes in the activity of ATP synthase were observed after I/R injury. These results suggest that the endogenous protective mechanisms of RPC and DM do preserve the mitochondrial function in heart when they act in combination.

\section{Key words}

Myocardial preconditioning • Mitochondria • Energy metabolism • Mitochondrial ATP synthase - Myocardial ischemic reperfusion injury

\section{Corresponding author}

M. Ferko, Institute for Heart Research, Slovak Academy of Sciences, Dúbravská cesta 9, P.O.Box 104, 84005 Bratislava 45, Slovak Republic. E-mail: usrdmife@savba.sk

\section{Introduction}

In the last decade the importance of cardioprotection has consistently risen in view of the increasing cardiovascular disease and coronary heart disease mortality in the countries of Europe (Nichols et al. 2014). Therefore, the investigation of all mechanisms that could contribute to preventing myocardial damage caused by ischemia/reperfusion (I/R) injury becomes an area of scientist interest. Especially, studying of mitochondrial function has become crucial in the basic research of cardiovascular $\mathrm{I} / \mathrm{R}$ injury (Andreas et al. 2011, Di Lisa and Bernardi 2006). Considering the capacity for aerobic energy production, the mitochondrial respiratory function is more indicative of heart viability than ATP levels (Wiedemann et al. 2013).

Several experimental models characterized by infarct size reduction following an experimental intervention have been observed (Neckáŕ et al. 2002, Ravingerová et al. 2009, Riess et al. 2004). It has been documented that hearts from streptozotocin-induced diabetic (DM) rats in the acute phase of disease are more resistant to ischemia (Tani and Neely 1988). Mechanism 
that may be involved in the cardioprotection is considered to be related with a greater resistance of diabetic heart to $\mathrm{Ca}^{2+}$ overload (Ziegelhöffer et al. 1997) and to the augmented calcium transients denoucing $\mathrm{Ca}^{2+}$ signaling (Ziegelhöffer et al. 2002). Further, ischemic preconditioning and its clinically more applicable form remote ischemic preconditioning (RPC), exerted by brief ischemic insults on an organ distant from the myocardium described by Przyklenk et al. (1993) manifests a similar protective effect. However, it is widely accepted that mitochondria contribute to mediation of cardioprotection against $\mathrm{I} / \mathrm{R}$ injury as signaling pathway end-effectors of both RPC and the experimental model of DM. This view is based on the fact that mitochondrial permeability transition pore is linked to the cardioprotection elicited by endogenous phenomenon of DM and RPC (Hausenloy and Yellon 2008, Ziegelhöffer et al. 2009).

Since the potential site of the cardioprotection in this scheme of experimental models is associated with changes in the mitochondrial membrane, it is likely that these processes linked to streptozotocin-induced DM and RPC could affect the mitochondrial function either. Moreover, considering that the mitochondrial function is required for optimal cardiac function including proper contractile activity, maintenance of energy substrates conserved in high-energy bonds of ATP and $\mathrm{pH}$ control, the maintaining adequate mitochondrial respiratory function is also fundamental for limiting the extent of damage caused by myocardial $\mathrm{I} / \mathrm{R}$ injury (Halestrap et al. 2007). Up to now, the preservation of mitochondrial respiration by RPC has been observed in rat skeletal muscle (Mansour et al. 2012), in neonatal rabbit hearts (Wang et al. 2008), and in patients undergoing coronary artery bypass graft surgery (Slagsvold et al. 2014). However, despite these positive findings, the actual role of mitochondrial bioenergetics in the myocardial protection conveyed by RPC and DM is still elusive. There is some evidence that the immediate protection by RPC might involve a preservation of mitochondrial state 3 respiration (Ferko et al. 2014) and, at the combined intervention of RPC and DM, the preservation of mitochondrial function is associated with an increase in the mitochondrial membrane fluidity (Ferko et al. 2015). Perhaps, the most prompting experimental task is to elucidate the nature of the model interaction that would result in the protective effect on the myocardium whether it is additive, synergistic or antagonistic.
The aim of this study was to evaluate the effect of cardioprotective RPC and DM model on mitochondrial respiratory function after $\mathrm{I} / \mathrm{R}$ injury of the heart. Key parameters of mitochondrial bioenergetics (mitochondrial basal and ADP-stimulated respiration), as well as the activity of ATP synthase were evaluated.

\section{Materials and Methods}

A factorial design was used to learn whether there is a response to the RPC and whether it is the same in control and diabetic condition (i.e. whether the factors RPC and DM interact with or potentiate/antagonise each other).

\section{Animals}

Animal experiments were conducted in accordance with Guide for the Care and Use of Laboratory Animals published by the US National Institutes of Health (NIH Publication No. 85-23, revised 1996) and were approved by the Animal Health and Animal Welfare Division of the State Veterinary and Food Administration of the Slovak Republic.

Male Wistar rats 12 weeks old (weight, 250 to $270 \mathrm{~g}$ ) were housed at $22 \pm 2{ }^{\circ} \mathrm{C}$ on a $12: 12 \mathrm{~h}$ photoperiod and were provided by food and water ad libitum. Animals were randomly allocated into four groups: 1) healthy control group, 2) diabetic group (DM), 3) healthy preconditioned group (RPC) and 4) diabetic preconditioned group (DM+RPC) ( $\mathrm{n}=7$ for each group). Diabetes was induced by intraperitoneal injection of a single dose of $65 \mathrm{mg} / \mathrm{kg}$ body weight streptozotocin in $0.1 \mathrm{M}$ citrate buffer. Eight days after streptozotocin injection, acute stage of DM had been fully developed. RPC was achieved with three cycles of $5 \mathrm{~min}$ ischemia and reperfusion using a pressure-cuff placing on the right hind limb of anesthetized rats. Diabetic stage of rats was monitored daily during eight days by measuring of glycosuria using Gluko PHAN strips (Erba-Lachema, Brno, Czech Republic) and by estimation of glucose (MultiCare, Biochemical system international, Florence, Italy), cholesterol and triacylglycerols (MultiCare, Biochemical system international, Florence, Italy) in the serum after excision of heart. Serum insulin was determined by the commercial RIA kit (Linco Research USA). Subsequently, the isolated hearts of all groups were subjected to ischemic-reperfusion test according to Langendorff. 


\section{Myocardial ischemia/reperfusion}

All animals were anesthetized by intraperitoneal injection of thiopenthal $(50 \mathrm{mg} / \mathrm{kg})$ given with heparine (500 IU). The hearts were excised rapidly and retrogradely perfused according to Langendorff at a constant perfusion pressure of $70 \mathrm{~mm} \mathrm{Hg}$ with KrebsHenseleit buffer consisting of $118 \mathrm{mmol} / 1 \mathrm{NaCl}$, $3.2 \mathrm{mmol} / 1 \mathrm{KCl}, 1.2 \mathrm{mmol} / 1 \mathrm{MgSO}_{4}, 25 \mathrm{mmol} / 1 \mathrm{NaHCO}_{3}$, $1.18 \mathrm{mmol} / 1 \mathrm{NaH}_{2} \mathrm{PO}_{4}, 2.5 \mathrm{mmol} / 1 \mathrm{CaCl}_{2}, 11.1 \mathrm{mmol} / \mathrm{l}$ glucose (pH 7.4). The oxygenation of buffer was performed with $95 \%$ oxygen and $5 \%$ carbon dioxide at $37^{\circ} \mathrm{C}$. Langendorff-perfused hearts were subjected to $30 \mathrm{~min}$ of ischemia followed by $40 \mathrm{~min}$ of post-ischemic reperfusion.

\section{Isolation of heart mitochondria}

Mitochondria were isolated by differential centrifugation from Langendorff-perfused hearts exposed to stabilization perfusion and post-ischemic reperfusion. Ice-cold isolation solution containing $180 \mathrm{mmol}^{-1} \mathrm{KCl}$, 4 mmol. ${ }^{-1}$ EDTA and $1 \%$ bovine serum albumin, $\mathrm{pH} 7.4$ was used. Briefly, after homogenization of the minced blood-free heart tissue digested with protease (Sigma P-6141, 2.5 mg. $\mathrm{g}^{-1}$ of tissue), the homogenate was centrifuged at $1000 \mathrm{~g}$ for $10 \mathrm{~min}$ at $4{ }^{\circ} \mathrm{C}$. The resulting supernatant was spun at $6200 \mathrm{~g}$ for $10 \mathrm{~min}$ at $4{ }^{\circ} \mathrm{C}$ to pellet mitochondria, which were resuspended in an albumin free isolation solution and spun again at $6200 \mathrm{~g}$ for $10 \mathrm{~min}$. Protein content was determined by Lowry et al. (1951).

\section{Mitochondrial respiration}

Oxygen consumption by isolated heart mitochondria was quantified by a high-resolution respirometry using Oxygraph-2k (Oroboros Instruments, Austria). Mitochondria were suspended in respiration medium $\mathrm{MiRO}_{6}$ (Fasching et al. 2014) in a $2 \mathrm{ml}$ chamber at $37^{\circ} \mathrm{C}$ and energised by adding glutamate $\left(10 \mathrm{mmol} . \mathrm{l}^{-1}\right)$ plus malate $\left(0.2 \mathrm{mmol} . \mathrm{l}^{-1}\right)$ for determination of CI-linked respiration and by adding the combination of malate $\left(0.2 \mathrm{mmol}^{-1}\right)$ plus octanoyl carnitine $\left(0.2 \mathrm{mmol} . \mathrm{l}^{-1}\right)$ for evaluation of fatty acids oxidation. State 2 respiration with both combinations of substrates were determined. State 3 respiration was induced by adding saturating concentration of ADP ( 2 mmol. $\left.\mathrm{l}^{-1}\right)$. Oxygen consumption was normalized to citrate synthase activity that was determined spectrophotometrically according to Eigentler et al. (2012).
ATP synthase activity

ATP synthase $\left(\mathrm{F}_{0} \mathrm{~F}_{1}\right.$ ATPase $)$ activity was evaluated spectrophotometrically at $700 \mathrm{~nm}$, in association with ATP hydrolysis according to method of Taussky and Shorr (1953). The reaction was carried out at $37^{\circ} \mathrm{C}$, in $1 \mathrm{ml}$ reaction medium (40 mmol. $\mathrm{l}^{-1}$ $\mathrm{MgCl}_{2}, 250 \mathrm{mmol}^{-1}$ imidazole buffer, $0.1 \mathrm{mmol}^{-1}$ 2,4-dinitrophenol, $\mathrm{pH} 7.4$ ), supplemented with $50 \mu \mathrm{l}$ mitochondrial protein with the concentration of $1 \mu \mathrm{g} . \mu \mathrm{l}^{-1}$. The reaction was initiated by adding $40 \mathrm{mmol} . \mathrm{l}^{-1}$ ATP and after 20 min stopped by ice cold $12 \%$ trichloroacetic acid. The released inorganic phosphate $\mathrm{P}_{\mathrm{i}}$ from ATP was quantified by reaction with ammonium molybdate. Results are reported as micromoles of ATP hydrolyzed per $\mathrm{g}$ of mitochondrial protein per hour $(\mu \mathrm{mol} . \mathrm{Pi} / \mathrm{g} / \mathrm{h})$.

\section{Statistical analysis}

All the values are expressed as mean \pm standard error of the mean (SEM). The experimental groups DM0-RPC0, DM1-RPC0, DM0-RPC1 and DM1-RPC1 represented each combination of factor levels as treatments (a factorial design). The hypotheses that were tested using two-way of variance with repeated measures tested concerned of whether the different levels of factor $\mathrm{RPC}$, or factor DM, make a difference in the response (the testing of so-called main effects), and whether the RPC and DM interaction term is significant (testing the degree of effect modification). The post-hoc pairwise comparisons were made with the Tukey-Kramer test. In the case of significant interaction one-way ANOVA approach was used to assess the main effects separately, in order not to disregard a main effect that occurs in the data analysis if there would be a biologically relevant interaction. When the assumptions of ANOVA were not met in the sample data, common nonparametric alternatives were used instead. Significance of both main effects was tested at the alpha level of 0.05 .

\section{Results}

\section{Metabolic state of experimental rats}

Rats with acute phase (8 days) streptozotocininduced diabetes mellitus displayed a significantly increased plasma glucose, triacylglycerols, cholesterol as well as decreased insulin levels in the blood compared with age-matched control rats (all $\mathrm{P} \leq 0.05$, Table 1). Plasma glucose and cholesterol in controls was routinely $5.23 \pm 0.19 \mathrm{mmol}^{-1} \mathrm{l}^{-1}$ and $1.37 \pm 0.25 \mathrm{~g} . \mathrm{l}^{-1}$ respectively. Both body weight and heart weight in the diabetic rats were 
significantly lower by $25 \%$ and $17 \%$ than the weights in the control rats (not shown).

Table 1. Metabolic state of control and streptozotocin-induced diabetic experimental rats.

\begin{tabular}{lcc}
\hline & Control group & Diabetic group \\
\hline $\begin{array}{l}\text { Plasma glucose } \\
\left(\text { mmol. } l^{-1}\right)\end{array}$ & $5.23 \pm 0.19$ & $17.86 \pm 0.64^{*}$ \\
$\begin{array}{l}\text { Triglycerols } \\
\left(\text { mmol. } l^{-1}\right)\end{array}$ & $1.11 \pm 0.27$ & $5.14 \pm 0.54^{*}$ \\
$\begin{array}{l}\text { Cholesterol } \\
\left.\text { (g. } l^{-1}\right)\end{array}$ & $1.37 \pm 0.25$ & $2.86 \pm 0.21^{*}$ \\
$\begin{array}{l}\text { Insulin } \\
\left(\text { ng. } \cdot l^{-1}\right)\end{array}$ & $1.18 \pm 0.08$ & $0.54 \pm 0.05^{*}$ \\
\hline
\end{tabular}

All values are expressed as mean \pm SEM. $n=7$ per group. * $\mathrm{P}<0.05$, compared with the control group.

\section{Mitochondrial respiration}

Parameters of oxidative phosphorylation of heart mitochondria were investigated by evaluating mitochondrial oxygen consumption in relation to either glutamate plus malate or malate plus octanoyl carnitine oxidation. Although mitochondrial ADP-stimulated respiration (state 3 respiration) was significantly decreased in all groups after $\mathrm{I} / \mathrm{R}$ injury compared to stabilization perfusion, no differences were observed in mitochondrial basal level respiration (state 2 respiration), irrespective of the substrate used (Figs 1A and 2A). However, in using substrates malate plus octanoyl carnitine, DM and DM+RPC group did not exhibit significant differences in the mitochondrial state 3 respiration after postischemic I/R injury compared with those respiration after stabilization perfusion (Figs 1B and 2B). In comparison with the control group at the end of $40 \mathrm{~min}$ postischemic reperfusion, the effect for streptozotocin-induced DM was directed towards tendency improvement of mitochondrial state 3 respiration, coupled with ATP synthesis (Fig. 2B). However, the observed increase did not reach statistical significance $(\mathrm{P}=0.07)$. RPC did not prevent the decrease in state 3 respiration observed in the control group subjected to $\mathrm{I} / \mathrm{R}$ injury. On the contrary, streptozotocin-induced DM with simultaneous effect of RPC was associated with a significant increase in this parameter up to almost a preischemic value of the control group. Such a less severe response to $\mathrm{I} / \mathrm{R}$ injury of $\mathrm{DM}+\mathrm{RPC}$ rats compared to nonpreconditioned $\mathrm{DM}$ rats indicated in fact an interaction between DM and RPC.

\section{Mitochondrial ATP synthase activity}

ATP synthase activity was evaluated in terms of its catalytic activity reflected by the $\mathrm{F}_{1} \mathrm{~F}_{0}$-ATPase rates of ATP hydrolysis. Mean mitochondrial ATP synthase activities during the stabilization perfusion and postischemic reperfusion protocol are depicted in Figure 3. In the initial preischemic activity of ATP synthase, no statistically significant differences were observed among groups. ATP synthase activity associated with the mitochondrial performace of phoshorylation was significantly decreased only in mitochondria from heart of control group subjected to I/R injury. Streptozotocininduced DM in like manner to RPC and DM+RPC preserved the activity of mitochondrial ATP synthase after $\mathrm{I} / \mathrm{R}$ injury at the level of value after the stabilization phase.
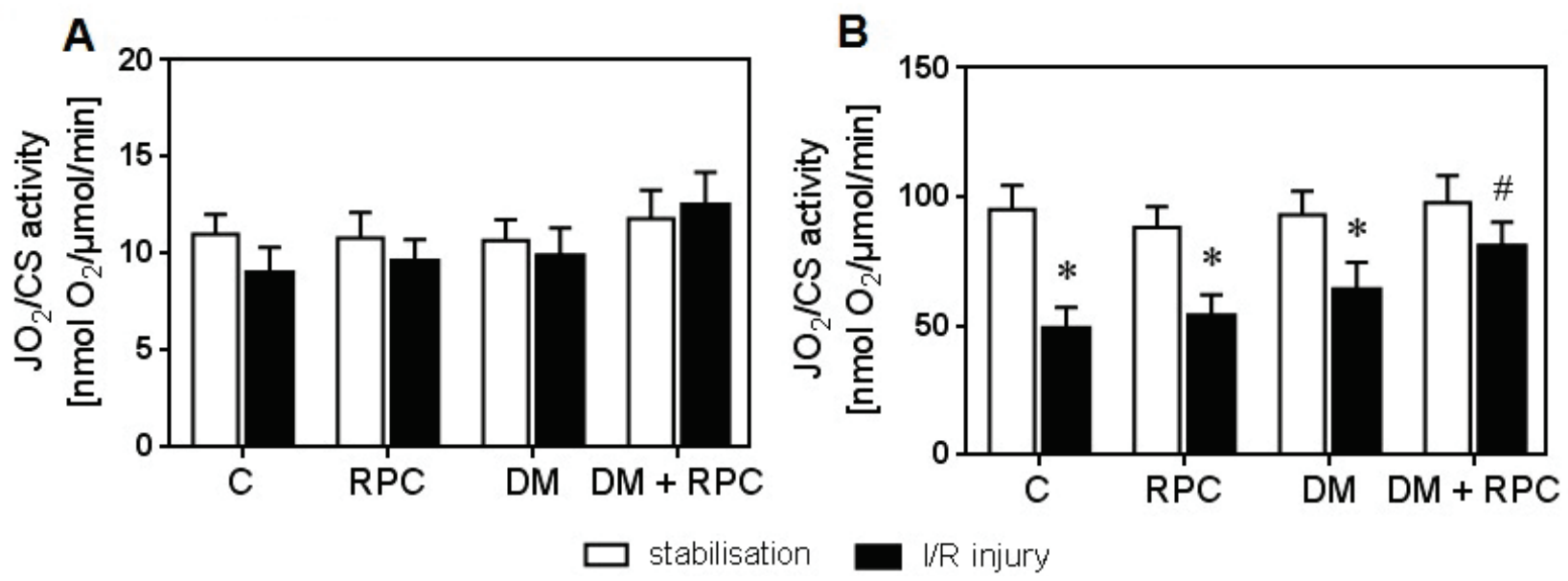

Fig. 1. A. Basal (State 2) respiration and B. ADP-stimulated (State 3) respiration activity in mitochondria isolated from control (C), streptozotocin-induced diabetic (DM), preconditioned (RPC) and preconditioned streptozotocin-induced diabetic (DM+RPC) heart subjected to ischemia/reperfusion. Energization was achieved with glutamate plus malate. $* \mathrm{P}<0.05$, compared with the stabilization perfusion, \# $P<0.05$, compared with control group after $I / R$ injury $(n=7)$. 
A

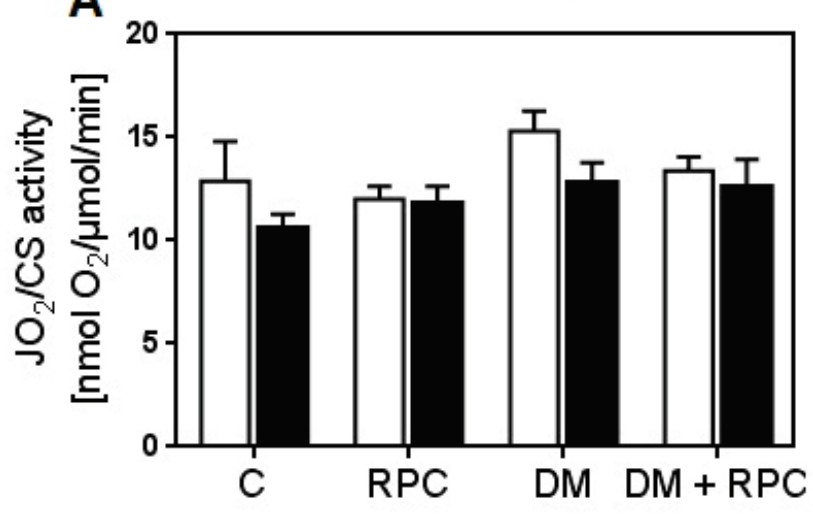

stabilisation
B

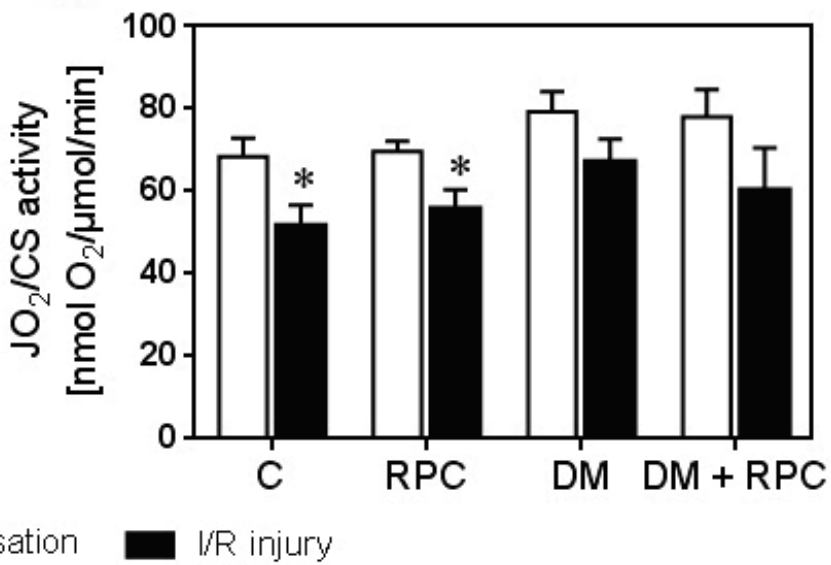

Fig. 2. A. Basal (State 2) respiration and B. ADP-stimulated (State 3) respiration activity in mitochondria isolated from control (C), streptozotocin-induced diabetic (DM), preconditioned (RPC) and preconditioned streptozotocin-induced diabetic (DM+RPC) heart subjected to ischemia/reperfusion. Energization was achieved with malate plus octanoylcarnitine. $* P<0.05$, compared with the stabilization perfusion $(n=7)$.

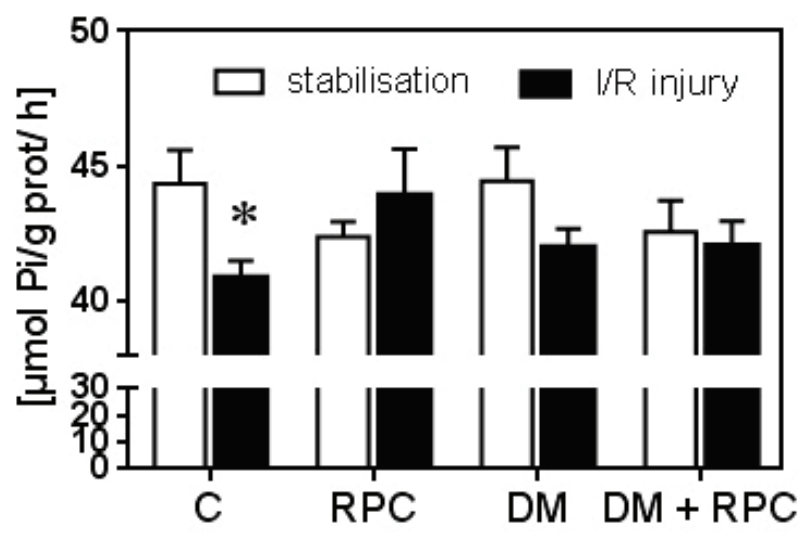

Fig. 3. ATP synthase activity in mitochondria isolated from control (C), streptozotocin-induced diabetic (DM), preconditioned (RPC) and preconditioned streptozotocin-induced diabetic (DM+RPC) heart subjected to ischemia/reperfusion. * $\mathrm{P}<0.05$, compared with the stabilization perfusion $(n=7)$.

\section{Discussion}

In some conditions, a number of changes related to endogenous protective mechanisms at the level of sarcolemmal and the mitochondrial membrane were recognized as the cause of the increased tolerance of the myocardium to a subsequent ischemic insult. This has been observed both, in the preconditioned myocardium by RPC and in streptozotocin-induced diabetic myocardium. However, it is not clear whether RPC and streptozotocin-induced DM act through similar mechanisms or synergise to enhance cardioprotection.

In this study we focused on investigation the effect of RPC on the mitochondrial respiratory chain and on the activity of mitochondrial ATP synthase complex in streptozotocin-induced diabetic myocardium. The information gained from these studies will help the investigators uncover mitochondrial respiratory function alterations that may be associated with protection of hearts during postischemic reperfusion.

Analyses conducted in this study yielded the following five key findings: 1) myocardial I/R injury impaired mitochondrial respiratory function, considering mitochondrial state 3 respiration and ATP synthase activity, 2) the protection bestowed by RPC to myocardium subsequently subjected to I/R injury did not include the preservation of mitochondrial respiratory function, 3) mitochondria in streptozotocin-induced diabetic myocardium exhibited tendency to improved postischemic mitochondrial function only in state 3 respiration, 4) RPC in streptozotocin-induced diabetic myocardium attenuated the decline the rate of ADP-stimulated oxygen consumption (state 3 ) caused by $\mathrm{I} / \mathrm{R}$ injury, 5) RPC, DM as well as DM+RPC rendered the preservation of mitochondrial ATP synthase activity after $\mathrm{I} / \mathrm{R}$ injury at the preischemic values.

Clearly, myocardial bioenergetics plays an essential role in the pathogenesis of $\mathrm{I} / \mathrm{R}$ injury. Previously in multiple studies, the impaired function of mitochondrial electron-transport chain associated with decrease in complex I-linked respiration has been reported as a consequence of myocardial I/R injury (Paradies et al. 2004, Lucas and Szweda 1999, Brookes et al. 2002). In addition, reactive oxygen species (ROS), produced by mitochondria during the sustained ischemia and reperfusion, are considered to be involved in the mechanism of myocardial damage caused by 
postischemic reperfusion (Khanna et al. 2008). Observed findings are consistent with our work demonstrating that the mitochondrial function was impaired as a results of significant reduction in oxygen consumption by mitochondria after addition of ATP (state 3 respiration) and the activity of complex $\mathrm{V}$ of mitochondrial respiratory chain (ATP synthase activity).

To date, little is known about the effect of ischemic preconditioning on mitochondrial respiratory function. Moreover, the observations are inconsistent. Several studies have investigated various effect of IPC in the context of the inhibition of mitochondrial respiratory chain in the presence of NADH-linked substrates (da Silva et al. 2003), the increase of basal state of mitochondrial respiration (Liem et al. 2008) and the improving of mitochondrial state 3 respiration during reperfusion (Crestanello et al. 2002). Although the most of physiological parameters, including myocardial infarct size, were reported to be ameliorated after application of RPC (Ferko et al. 2015, Zhu et al. 2013), we did not observe improvement in mitochondrial respiratory function corresponding to the earlier study (Ferko et al. 2014). However, data from absorption spectrophotometry suggest that RPC prevented the decrease of ATP synthase activity after ischemia-reperfusion and that this contributed to the preservation of mitochondrial function following $\mathrm{I} / \mathrm{R}$ injury. This is consistent with previous analysis of Kobara et al. (1996) who reported the preservation of ATP synthase activity after sustained $I / R$ injury in the preconditioned hearts of rats. There is some evidence that RPC might improve respiratory efficiency by preventing uncoupling of oxidative phosphorylation. It has been proposed that the conformation and activity of mitochondrial membrane-bound enzymes such as ATP synthase can be affected by the changes in membrane properties, especially in membrane fluidity (Mazzanti et al. 1992, Waczulikova et al. 2007). Mitochondrial membrane fluidity is an important biophysical characteristic which refers to the extent of molecular disorder and molecular motion within a lipid bilayer. Fluidity is inversely related to mebrane microviscosity. The physical state of membrane phospholipids acts directly to regulate the activity of membrane-bound proteins, such as the ion channels, receptors, and other membrane proteins. Likely an increase in membrane fluidity can actually help ease the rotary-catalysis movement and thus increase the ATP synthase activity, which is supported by finding a positive association between both characteristics (Patel and Katyare 2006). A similar effect has been observed in our previous work demonstrated the beneficial protective effect of RPC on the heart mitochondria causing an elimination of I/R-induced massive depression of mitochondrial membrane fluidity (Ferko et al. 2014).

Several studies have been carried out to evaluate the alterations in mitochondrial functions of streptozotocin-induced diabetic rats (Raza et al. 2011, Ferko et al. 2006, Tomita et al. 1996). In the study by Tomita et al. (1996), the respiratory activity of myocardial mitochondria indicated a significant reduction in the rate of oxygen consumption in state 3 using either succinate or glutamate-malate as substrates. However, the study concerning STZ-treated rats has been performed as far as 8 weeks after the induction of diabetes. In contrast to this finding, 8-day lasting acute STZ-induced diabetes mellitus offer a support to preservation of the transmembrane proton gradient as well as the coupling of oxidation to phosphorylation demonstrated by preserved ADP:O (Ferko et al. 2006). Whether mitochondrial respiration is involved in mechanism of cardioprotection against $\mathrm{I} / \mathrm{R}$ injury induced by the 8-day experimental model of streptozotocin-induced diabetes mellitus, is still unknown. During postischemic reperfusion, in diabetic myocardium, we observed a decline in the rate of ADP-stimulated oxygen consumption (state 3 respiration) with both substrate combination, a finding that is consistent with a decrease in the phosphorylation capacity of the mitochondria (decreased ATP synthase activity). However, there was a trend towards improvement in mitochondrial respiratory function after $I / R$ injury compared DM with the control group. In basal respiration no statistically significant difference was observed after $\mathrm{I} / \mathrm{R}$ injury when either glutamate + malate, or malate + octanoyl carnitine was used as a substrate.

Several published studies were designed to elucidate the possible synergistic or additional benefit of combination of different phenomena conferring to myocardium the increased ischemic tolerance. The study of Manintveld et al. (2009) demonstrated that postconditioning does not provide additional protection in preconditioned hearts irrespective of the preconditioning stimulus. The authors explained the lack of additional protection by the fact that both of observed phenomena mediate the cardioprotection via mechanism including NO synthase (Manintveld et al. 2009). In our study, we observed the additional protective effect of RPC on mitochondrial function when the streptozotocin-induced diabetes mellitus was presented. This may either indicate that the simultaneous action of two cardioprotective 
phenomena provides more intense stimulus probably inducing cardioprotective pathways converge at the level of the mitochondrial respiratory chain. On the basis of these new findings, we propose that a larger number of brief periods of ischemia and reperfusion applicated in hind-limb RPC could provide cardioprotection at a larger scale via promoting the mitochondrial respiratory function. We suggest that RPC and streptozotocin-induced DM may be based on the different mechanisms influencing the mitochondrial membrane. Therefore preconditioning may confer additional benefit in diabetic rat myocardium.

\section{Conclusion}

Our findings indicate that RPC may provide additional protection of streptozotocin-induced diabetic rat myocardium at the mitochondrial level. Although the early cardioprotective effect of RPC synergizes with the other cardioprotective stimulus mediated by experimental model of streptozotocin-induced diabetes mellitus only in improving the state 3 respiration stimulated by glutamate and malate, the cardioprotective effect both of them is sufficiently preserved.

\section{Conflict of Interest}

There is no conflict of interest.

\section{Acknowledgements}

This work was supported by grants VEGA 2/0133/15, 2/0201/15; APVV-0102-11, APVV-15-0119.

\section{References}

ANDREAS M, SCHMID AI, KEILANI M, DOBERER D, BARTKO J, CREVENNA R, MOSER E, WOLZT M: Effect of ischemic preconditioning in skeletal muscle measured by functional magnetic resonance imaging and spectroscopy: a randomized crossover trial. J Cardiovasc Magn Reson 13: 32, 2011.

BROOKES PS, DIGERNESS SB, PARKS DA, DARLEY-USMAR V: Mitochondrial function in response to cardiac ischemia-reperfusion after oral treatment with quercetin. Free Radic Biol Med 32: 1220-1228, 2002.

CRESTANELLO JA, DOLIBA NM, BABSKY AM, DOLIBA NM, NIIBORI K, OSBAKKEN MD, WHITMAN GJ: Mitochondrial function during ischemic preconditioning. Surgery 131: 172-178, 2002.

DA SILVA MM, SARTORI A, BELISLE E, KOWALTOWSKI AJ: Ischemic preconditioning inhibits mitochondrial respiration, increases $\mathrm{H} 2 \mathrm{O} 2$ release, and enhances $\mathrm{K}+$ transport. Am J Physiol Heart Circ Physiol 285: H154-H162, 2003.

DI LISA FD, BERNARDI P: Mitochondria and ischemia-reperfusion injury of the heart: fixing a hole. Cardiovasc Res 70: 191-199, 2006.

EIGENTLER A, DRAXL A, WEITHÜCHTER A, KUZNETSOV AV, LASSNIG B, GNAIGER E: Laboratory protocol: citrate synthase. Mitochondrial marker enzyme. Mitochondr Physiol Network 17.04: 1-11, 2012.

FASCHING M, FONTANA-AYOUB M, GNAIGER E: Mitochondrial Respiration Medium - MiR06. Mitochondr Physiol Network 14.13: 1-4, 2014.

FERKO M, GVOZDJAKOVÁ A, KUCHARSKÁ J, MUJKOSOVÁ J, WACZULÍKOVÁ I, STYK J, RAVINGEROVÁ T, ZIEGELHÖFFER-MIHALOVICOVÁ B, ZIEGELHÖFFER A: Functional remodeling of heart mitochondria in acute diabetes: interrelationships between damage, endogenous protection and adaptation. Gen Physiol Biophys 25: 397-413, 2006.

FERKO M, KANCIROVÁ I, JAŠOVÁ M, ČARNICKÁ S, MURÁRIKOVÁ M, WACZULÍKOVÁ I, SUMBALOVÁ Z, KUCHARSKÁ J, ULIČNÁ O, RAVINGEROVÁ T, ZIEGELHÖFFER A: Remote ischemic preconditioning of the heart: protective responses in functional and biophysical properties of cardiac mitochondria. Physiol Res 63 (Suppl 4): S469-S478, 2014.

FERKO M, KANCIROVÁ I, JAŠOVÁ M, WACZULÍKOVÁ I, ČARNICKÁ S, KUCHARSKÁ J, ULIČNÁ O, VANČOVÁ O, MURÁRIKOVÁ M, RAVINGEROVÁ T, ZIEGELHÖFFER A: Participation of heart mitochondria in myocardial protection against ischemia/reperfusion injury: benefit effects of short-term adaptation processes. Physiol Res 64 (Suppl 5): S617-S625, 2015.

GHO BC, SCHOEMAKER RG, VAN DEN DOEL MA, DUNCKER DJ, VERDOUW PD: Myocardial protection by brief ischemia in noncardiac tissue. Circulation 94: 2193-2200, 1996. 
HALESTRAP AP, CLARKE SJ, KHALIULIN I: The role of mitochondria in protection of the heart by preconditioning. Biochim Biophys Acta 1767: 1007-1031, 2007.

HAUSENLOY DJ, YELLON DM: Remote ischaemic preconditioning: underlying mechanisms and clinical application. Cardiovasc Res 79: 377-386, 2008.

HEIDBREDER M, NAUMANN A, TEMPEL K, DOMINIAK P, DENDORFER A: Remote vs. ischaemic preconditioning: the differential role of mitogen-activated protein kinase pathways. Cardiovasc Res 78: 108-115, 2008.

KHANNA G, DIWAN V, SINGH M, SINGH N, JAGGI AS: Reduction of ischemic, pharmacological and remote preconditioning effects by an antioxidant $\mathrm{N}$-acetyl cysteine pretreatment in isolated rat heart. Yakugaku Zasshi 128: 469-477, 2008.

KOBARA M, TATSUMI T, MATOBA S, YAMAHARA Y, NAKAGAWA C, OHTA B, MATSUMOTO T, INOUE D, ASAYAMA J, NAKAGAWA M: Effect of ischemic preconditioning on mitochondrial oxidative phosphorylation and high energy phosphates in rat hearts. J Mol Cell Cardiol 28: 417-428, 1996.

KONSTANTINOV IE, ARAB S, KHARBANDA RK, LI J, CHEUNG MM, CHEREPANOV V, DOWNEY GP, LIU PP, CUKERMAN E, COLES JG, REDINGTON AN: The remote ischemic preconditioning stimulus modifies inflammatory gene expression in humans. Physiol Genomics 19: 143-150, 2004.

LIEM DA, MANINTVELD OC, SCHOONDERWOERD K, MCFALLS EO, HEINEN A, VERDOUW PD, SLUITER W, DUNCKER DJ: Ischemic preconditioning modulates mitochondrial respiration, irrespective of the employed signal transduction pathway. Transl Res 151: 17-26, 2008.

LUCAS DT, SZWEDA LI: Declines in mitochondrial respiration during cardiac reperfusion: age-dependent inactivation of alpha-ketoglutarate dehydrogenase. Proc Natl Acad Sci U S A 96: 6689-6693, 1999.

MANINTVELD OC, HEKKERT MT, VAN DER PLOEG NT, VERDOUW PD, DUNCKER DJ: Interaction between pre- and postconditioning in the in vivo rat heart. Exp Biol Med (Maywood) 234: 1345-1354, 2009.

MANSOUR Z, BOUITBIR J, CHARLES AL, TALHA S, KINDO M, POTTECHER J, ZOLL J, GENY B: Remote and local ischemic preconditioning equivalently protects rat skeletal muscle mitochondrial function during experimental aortic cross-clamping. J Vasc Surg 55: 497-505.e1., 2012.

MAZZANTI L, RABINI RA, BIAGINI G, PUGNALONI A, DE PIRRO R, FALOIA E, MANCINI V, ROMANINI C, CESTER N: Changes in membrane fluidity and $\mathrm{Na}+/ \mathrm{K}+$-ATPase activity during human trophoblast cell culture. Eur J Biochem 206: 881-885, 1992.

NECKÁR J, PAPOUSEK F, NOVÁKOVÁ O, OST'ÁDAL B, KOLÁR F: Cardioprotective effects of chronic hypoxia and ischaemic preconditioning are not additive. Basic Res Cardiol 97: 161-167, 2002.

NICHOLS M, TOWNSEND N, SCARBOROUGH P, RAYNER M: Cardiovascular disease in Europe 2014: epidemiological update. Eur Heart J 35: 2950-2959, 2014.

PARADIES G, PETROSILlO G, PISTOLESE M, Di VENOSA N, FEDERICI A, RUGGIERO FM: Decrease in mitochondrial complex I activity in ischemic/reperfused rat heart: involvement of reactive oxygen species and cardiolipin. Circ Res 94: 53-59, 2004.

PATEL SP, KATYARE SS. Insulin-status-dependent modulation of FoF1-ATPase activity in rat liver mitochondria. Lipids 41: 695-703, 2006.

PRZYKLENK K, BAUER B, OVIZE M, KLONER RA, WHITTAKER P: Regional ischemic 'preconditioning' protects remote virgin myocardium from subsequent sustained coronary occlusion. Circulation 87: 893-899, 1993.

RAVINGEROVA T, MATEJIKOVA J, PANCZA D, KOLAR F: Reduced susceptibility to ischemia-induced arrhythmias in the preconditioned rat heart is independent of PI3-kinase/Akt. Physiol Res 58: 443-447, 2009.

RAZA H, PRABU SK, JOHN A, AVADHANI NG: Impaired mitochondrial respiratory functions and oxidative stress in streptozotocin-induced diabetic rats. Int J Mol Sci 12: 3133-3147, 2011.

RIESS ML, STOWE DF, WARLTIER DC: Cardiac pharmacological preconditioning with volatile anesthetics: from bench to bedside? Am J Physiol Heart Circ Physiol 286: H1603-H1607, 2004.

SHIMIZU M, TROPAK M, DIAZ RJ, SUTO F, SURENDRA H, KUZMIN E, LI J, GROSS G, WILSON GJ, CALLAHAN J, REDINGTON AN: Transient limb ischaemia remotely preconditions through a humoral mechanism acting directly on the myocardium: evidence suggesting cross-species protection. Clin Sci (Lond) 117: 191-200, 2009. 
SLAGSVOLD KH, ROGNMO O, HØYDAL M, WISLØFF U, WAHBA A: Remote ischemic preconditioning preserves mitochondrial function and influences myocardial microRNA expression in atrial myocardium during coronary bypass surgery. Circ Res 114: 851-859, 2014.

TANI M, NEELY JR: Hearts from diabetic rats are more resistant to in vitro ischemia: possible role of altered Ca2+ metabolism. Circ Res 62: 931-940, 1988.

TOMITA M, MUKAE S, GESHI E, UMETSU K, NAKATANI M, KATAGIRI T: Mitochondrial respiratory impairment in streptozotocin-induced diabetic rat heart. Jpn Circ J 60: 673-682, 1996.

WACZULIKOVA I, HABODASZOVA D, CAGALINEC M, FERKO M, ULICNA O, MATEASIK A, SIKUROVA L, ZIEGELHÖFFER A: Mitochondrial membrane fluidity, potential, and calcium transients in the myocardium from acute diabetic rats. Can J Physiol Pharmacol 85: 372-381, 2007.

WANG L, OKA N, TROPAK M, CALLAHAN J, LEE J, WILSON G, REDINGTON A, CALDARONE CA: Remote ischemic preconditioning elaborates a transferable blood-borne effector that protects mitochondrial structure and function and preserves myocardial performance after neonatal cardioplegic arrest. $J$ Thorac Cardiovasc Surg 136: 335-342, 2008.

WIEDEMANN D, SCHACHNER T, BONAROS N, DORN M, ANDREAS M, KOCHER A, KUZNETSOV AV: Impact of cold ischemia on mitochondrial function in porcine hearts and blood vessels. Int J Mol Sci 14: 22042-22051, 2013.

WOLFRUM S, SCHNEIDER K, HEIDBREDER M, NIENSTEDT J, DOMINIAK P, DENDORFER A: Remote preconditioning protects the heart by activating myocardial PKCepsilon-isoform. Cardiovasc Res 55: 583-589, 2002.

ZHU S-B, LIU Y, ZHU Y, YIN G-L, WANG R-P, ZHANG IY, ZHU IJ, JIANG W: Remote preconditioning, perconditioning, and postconditioning: a comparative study of their cardioprotective properties in rat models. Clinics 68: 263-268, 2013.

ZIEGELHÖFFER A, RAVINGEROVÁ T, STYK J, SEBOKOVÁ J, WACZULÍKOVÁ I, BREIER A, DZURBA A, VOLKOVOVÁ K, CÁRSKY J, TURECKÝ L: Mechanisms that may be involved in calcium tolerance of the diabetic heart. Mol Cell Biochem 176: 191-198, 1997.

ZIEGELHÖFFER A, RAVINGEROVÁ T, WACZULÍKOVÁ I, CÁRSKY J, NECKÁR J, ZIEGELHÖFFERMIHALOVICOVÁ B, STYK J: Energy transfer in acute diabetic rat hearts: adaptation to increased energy demands due to augmented calcium transients. Ann N Y Acad Sci 967: 463-468, 2002.

ZIEGELHÖFFER A, WACZULÍKOVÁ I, FERKO M, KINCELOVÁ D, ZIEGELHÖFFER B, RAVINGEROVÁ T, CAGALINEC M, SCHÖNBURG M, ZIEGELHOEFFER T, SIKUROVÁ L, ULICNÁ O, MUJKOSOVÁ J: Calcium signaling-mediated endogenous protection of cell energetics in the acutely diabetic myocardium. Can J Physiol Pharmacol 87: 1083-1094, 2009. 